\title{
Pairing the Cholinergic Agonist Carbachol with Patterned Schaffer Collateral Stimulation Initiates Protein Synthesis in Hippocampal CA1 Pyramidal Cell Dendrites via a Muscarinic, NMDA-Dependent Mechanism
}

\author{
Sherry Feig' and Peter Lipton ${ }^{2,3}$ \\ Departments of ${ }^{1}$ Anatomy and ${ }^{2}$ Physiology and ${ }^{3}$ Center for Neuroscience, University of Wisconsin Medical School, \\ Madison, Wisconsin 53706
}

\begin{abstract}
Effects of afferent stimulation on local synthesis of protein in CA1 pyramidal cell dendrites were studied using light microscope autoradiography. Tissue was fixed with paraformaldehyde immediately after 3 min exposure to ${ }^{3} \mathrm{H}$-leucine in order to trap ${ }^{3} \mathrm{H}$ associated with macromolecules.

The rate of ${ }^{3} \mathrm{H}$-leucine incorporation into dendrites of resting hippocampal slices was $10 \%$ the rate of incorporation into cell somata. Ninety percent of the incorporation into the somata was inhibited by cycloheximide $(300 \mu \mathrm{M})$; none of the incorporation into dendrites was blocked by cycloheximide. Thus, there is no measurable extramitochondrial synthesis of protein in the dendrites of the resting slice.
\end{abstract}

Slices were exposed to $50 \mu \mathrm{M}$ carbachol and the Schaffer collateral afferents to the CA1 pyramidal cells were stimulated intermittently at $10 \mathrm{~Hz}$ over a 20 min period. In this case, ${ }^{3} \mathrm{H}$ incorporation into dendrites was increased almost threefold over resting levels, with no effect on label over the cell somata. There was no associated increase in uptake of tree ${ }^{3} \mathrm{H}$-leucine, and the increase in label was completely blocked by cycloheximide. Thus, associating carbachol and afferent stimulation appears to activate de novo protein synthesis in the dendrites. Neither the carbachol alone nor the Schaffer collateral stimulation alone increased synthesis.

The activation of dendrite synthesis was completely blocked by $5 \mu \mathrm{M}$ atropine, and also by $50 \mu \mathrm{M}$ D-aminophosphonovalerate. It did not occur when carbachol was paired with steady stimulation of the Schaffer collaterals at $1 \mathrm{~Hz}$ for $20 \mathrm{~min}$, rather than with the patterned high-frequency stimulation.

Thus, associating a cholinergic agonist with a level of neural activity that occurs in CA3 and CA1 pyramidal cells during exploratory behavior (Muller et al., 1987) initiates local protein synthesis in target dendrites. This effect is dependent on muscarinic cholinergic receptors and NMDA-type glutamate receptors. The possible relationship of this phenomenon to mechanisms of learning is discussed.

[Key words: ACh, dendrities, hippocampus, learning, NMDA, protein synthesis]

\footnotetext{
Received June 24, 1992; revised Aug. 31, 1992; accepted Sept. 10, 1992.

We acknowledge the excellent technical assistance provided by Goeffrey Guerts and Randall Massey. This work was supported by NSF Grant BNS9021629.

Correspondence should be addressed to Peter Lipton, Department of Physiology, 1300 University Avenue, University of Wisconsin, Madison, WI 53706.

Copyright (c) 1993 Society for Neuroscience $0270-6474 / 93 / 131010-12 \$ 05.00 / 0$
}

The protein composition of postsynaptic dendrites must be a major factor in the determination of neural behavior. While a great deal of attention has been focused on posttranslational modification of dendritic protein (Lisman, 1989; Nelson et al., 1989; Oliver et al., 1989), very little is known about the regulation of turnover of these proteins. The paucity of polysomes in distal dendrites and the demonstration of dendritic flow in a few studies have led to the conclusion that the large bulk of new protein in dendrites originates by flow from the cell somata, as it does in axons (Kreutzberg et al., 1973; Grafstein and Forman, 1980). However, ribosomes and polysomes are found in distal dendrites (Steward et al., 1988), and at least two mRNA species have heen ohserved there (Burgin et al., 1990; Kleiman et al., 1990), suggesting that there may be local synthesis. Indeed, there is now direct evidence that dendrites that are being reinnervated in situ (Steward, 1986) and dendrites in cultured neurons (Torre and Steward, 1992), as well as isolated dendritic fragments (Rao and Steward, 1991), do synthesize extramitochondrial protein.

The fact that only a very small fraction of total protein is synthesized in dendrites suggests that this local synthesis has a specific functional role, and the observation that dendritic ribosomes occur largely under dendritic spines (Steward et al., 1988) has led to the suggestion that afferent neural activity might regulate this local synthesis (Lipton and Robacker, 1983; Gordon-Weeks, 1988). Such a mechanism could play a role in neural plasticity, as alterations in synthesis should be restricted to active synapses, as required by Hebbian models (Lisman, 1989). While stimulatory effects of afferent stimulation on protein synthesis have been described in neuronal cell somata (Abdul-Ghani et al., 1980; Hyson and Rubel, 1989; Uenishi et al., 1991), there are no descriptions of effects of afferent stimulation on synthesis of protein in intact dendrites.

In this study, the hippocampal slice was used to examine the effects of afferent pathway stimulation on protein synthesis in CAl pyramidal cell layer dendrites. The effects of afferent pathway stimulation alone, and in the presence of a cholinergic agonist, were studied to see whether associating two stimuli that may occur together during learning had unique effects. The importance of the cholinergic system to learning is well established (Dunnett et al., 1982; Chrobak et al., 1989; Ridley et al., 1991). A pattern of afferent axon stimulation that resembles that occurring during prolonged exploratory activity by an animal (Muller ct al., 1987) was applied, either alone or in combination with the cholinergic agonist carbachol. Synthesis in dendrites 
was studied using autoradiography, following exposures of slices to precursor amino acid. These exposures were of very brief durations in order to eliminate any contribution from dendritic flow. Associating the stimulus with carbachol had profound effects on protein synthesis in the dendrites.

\section{Materials and Methods}

\section{Slice incubation}

Transverse hippocampal slices were prepared from guinea pigs as previously described (Feig and Lipton, 1990). Freshly dissected hippocampi were sliced on a Vibratome at a nominal thickness of $500 \mu \mathrm{m}$. They were placed in a "preincubation" buffer for $45 \mathrm{~min}$ and then transferred to standard buffer for a further $2 \mathrm{hr}$. Experimental procedures were then carried out between 2.75 and $7 \mathrm{hr}$ of killing the animal. Standard buffer consisted of (in mM) $120 \mathrm{NaCl}, 26 \mathrm{NaHCO}_{3}, 1.3 \mathrm{MgSO}_{4}, 1.2 \mathrm{KH}_{2} \mathrm{PO}_{4}$, $1.2 \mathrm{CaCl}_{2}$, and 10 glucose, with $95 \% \mathrm{O}_{2}, 5 \% \mathrm{CO}_{2}(\mathrm{pH} 7.4)$. Preincubation buffer was the same as standard buffer except $0 \mathrm{mM} \mathrm{CaCl}_{2}$ and $10 \mathrm{mM}$ $\mathrm{MgSO}_{4}$. All incubations were carried out at $36^{\circ} \mathrm{C}$. The preincubation allows good morphological and electrophysiological preservation of CA1 pyramidal cells (Feig and Lipton, 1990) (see Results).

\section{Experimental procedure}

Electrophysiological studies. A pair of adjacent slices was placed on a nylon bolting cloth grid in an electrophysiological chamber and perfused with standard buffer (Kass and Lipton, 1982). One member of each pair was stimulated with bipolar tungsten electrodes in stratum radiatum of CA2; responses in the CA1 pyramidal cell layer were recorded with a tungsten microelectrode (2-5 M 2 ). Slices were stimulated once every 2 min until a steady population spike response was recorded. Transmitter agonists and/or antagonists were added as described in the figure captions, and a new steady state was obtained after a further $15 \mathrm{~min}$. The stimulation paradigm was then begun. In all but one study, $1 \mathrm{~min}$ of stimulation is followed by $4 \mathrm{~min}$ of silence, repeated four times. During the $1 \mathrm{~min}$, the repeated pattern was $3 \mathrm{sec}$ of $10 \mathrm{~Hz}$ stimulation followed by $4 \mathrm{sec}$ of silence. The overall paradigm of $1 \mathrm{~min}$ on, $4 \mathrm{~min}$ off was chosen to mimic events that might occur during multiple trial learning. Ten hertz was chosen because it is an average firing frequency for activated hippocampal place cells (Muller et al., 1987). The intermittent pattern was chosen to eliminate attenuation of the signal during stimulation. The above paradigm is termed the "standard stimulus paradigm." In one study the stimulation pattern was altered so that the same number of pulses were delivered uniformly throughout the $20 \mathrm{~min}$ stimulation time period.

${ }^{3} \mathrm{H}$-leucine incorporation. At the end of the stimulus paradigm, the grid was placed into buffer of the same composition used during stimulation, containing ${ }^{3} \mathrm{H}$-leucine $(500 \mu \mathrm{Ci} / \mathrm{ml}$; specific activity, $60 \mathrm{Ci} /$ $\mathrm{mmol}$ ) added as an aqueous solution. The two slices were removed after 3 min and fixed immediately with ice-cold $4 \%$ paraformaldehyde. In one treatment they were fixed in ice-cold $2 \%$ glutaraldehyde, $2 \%$ paraformaldehyde in order to retain free ${ }^{3} \mathrm{H}$-leucine in the tissue (Peters and Ashley, 1967; Raley-Susman and Lipton, 1990). After osmication and dchydration, tissuc was cmbcddcd in Epon; thin ( $1 \mu \mathrm{m})$ sections were cut at $150 \mu \mathrm{m}$ from the upper surface of the slice. Sections were coated with Kodak NTB2 emulsion, exposed for $7-14 \mathrm{~d}$ at $4^{\circ} \mathrm{C}$, and developed with D-19 at $14^{\circ} \mathrm{C}$ for 2.5 min using standard autoradiographic techniques (Cowan et al., 1972). Sections were poststained with toluidine blue $(1 \%$, in $1 \%$ borax) in order to improve visualization of dendrites. Toluidine blue staining does not affect grain counts over frozen tissue sections (Hendrickson et al., 1972). To determine whether this was the case for the Epon-embedded sections, sample cells with overlying silver grains from unstained $1 \mu \mathrm{m}$ sections were drawn before staining, stained for $30 \mathrm{sec}$ with toluidine blue, gently washed with distilled water, dried and coverslipped, and redrawn. There was no alteration in the grain numbers. Thus, $1 \%$ toluidine blue does not alter emulsion grain density over plastic-embedded sections.

Quantitative autoradiography. ${ }^{3} \mathrm{II}$ incorporation into dendrites or somata was quantified as grains $/ \mu \mathrm{m}^{2}$ of those tissue elements in a particular field.

The typical location of the CAl dendritic fields that were analyzed is shown in Figure $1 A$. It begins about $50 \mu \mathrm{m}$ from the border of stratum lacunosum moleculaire and extends for $150 \mu \mathrm{m}$ toward the pyramidal layer, ending about $200 \mu \mathrm{m}$ from the layer; the length extends for 1 $\mathrm{mm}$. Within that region, four equally spaced circular fields with di- ameters of $150 \mu \mathrm{m}$ were analyzed. Fields were observed in the light microscope at high power $(100 \times)$; dendrites and overlying silver grains were drawn using the camera lucida. Only dendrites whose long axes were within $10^{\circ}$ of the vertical direction and that had widths between 1.0 and $2.5 \mu \mathrm{m}$ were drawn and analyzed. (Compare Fig. $1 B, C$; dendrites labeled with arrowheads were those that were drawn.) These orientations and widths are those of dendrites that were observed to be attached to pyramidal layer cells in cases where the entire cell was able to be followed. This criterion undoubtedly excluded short dendritic processes that were parts of pyramidal layer neurons (see Fig. $1 B$ ), but it meant that the dendrites that were analyzed were very likely to be parts of such neurons. The grains within dendrites were counted and the combined areas of the dendrites were measured with a software program (sIGMA SCAN, Jandel Scientific). Final values of grain density for each slice were the means from the four fields. Values for the different fields in the same slice were similar, with SEM values not exceeding $10 \%$. Tests for statistical significance of effects of a treatment used Student's $t$ test.

Only grains that were fully within dendrites were counted. This is seen in Figure 1, $B$ and $C$. Grain diameter is approximately $0.4 \mu \mathrm{m}$, and the half-radius for these grains is approximately $0.3 \mu \mathrm{m}$ (Rogers, 1973). For these values, it can be calculated graphically that, if a grain within a dendrite is just touching the border of the dendrite, there is a $75 \%$ probability that the source of that grain is within the dendrite. This probability increases to $96 \%$ if the edge of the grain is $0.4 \mu \mathrm{m}$ from the border of the dendrite (Rogers, 1973). The average dendrite diameter is $1.5 \mu \mathrm{m}$ (see Results), so the large majority (between $75 \%$ and $96 \%$ ) of the grains that were counted come from ${ }^{3} \mathrm{H}$-leucine localized within the dendrite. This estimate rests on the assumption that actual ${ }^{3} \mathrm{H}$ incorporation within and outside dendrites is equal. In fact, the grain density in the region $1.5 \mu \mathrm{m}$ on either side of resting dendrites was approximately half the grain density within the dendrites $(0.011 \pm 0.003$ vs $0.021 \pm 0.002$ in six fields that were measured). This will favor intradendritic origin of the ${ }^{3} \mathrm{H}$ even more than the above calculation indicates.

For cell somata, $20 \mathrm{CA} 1$ pyramidal layer somata per slice (five cells with visible nucleoli per field) were drawn and analyzed as described for dendrites. The cells were directly above the analyzed apical dendritic fields. Grain densities for different cells in a slice were similar; the SEM for the 20 cells did not exceed $5 \%$.

\section{Materials}

${ }^{3} \mathrm{H}$-Leucine was from DuPont (NET 135H). All drugs and transmitter agonists or antagonists were from Sigma (St. Louis). Buffer reagents were from Mallinckrodt (Paris, KY).

\section{Results}

\section{Integrity of the slice preparation}

Previous measurements had shown very low levels of protein synthesis in brain slices (Dunlop et al., 1974). Furthermore, the pattern of incorporation was very different from in situ. The ability of neurons to synthesize protein was greatly compromised in the slice. Synthesis was very patchy, and declined greatly in the deeper portion of the slice. Much of the synthesis occurred in capillary endothelial cells (White, 1980). Using a preincubation procedure that greatly improves the morphological preservation of neurons in guinea pig hippocampal slices (Feig and Lipton, 1990) greatly improved synthesis in the slice, as illustrated in Figure $2 A-D$. Overall synthesis of protein is uniform throughout the thickness of the slice (except for the surface $50 \mu \mathrm{m}$, which is damaged). Within the plane of the slice, this pattern is very similar to that seen in situ, with high levels of label over the principle neuronal cell layers compared with neuropil (Thilmann et al., 1986). The identification of incorporated ${ }^{3} \mathrm{H}$-leucine with protein is substantiated by its almost complete abolition by cycloheximide (Fig. $2 E$ ). The pattern of accumulation of free ${ }^{3} \mathrm{H}$-leucine in the slice (Fig. $2 F$ ) is strikingly different from that of protein synthesis. The contrast between cell body layers and neuropil is much less. This could result 

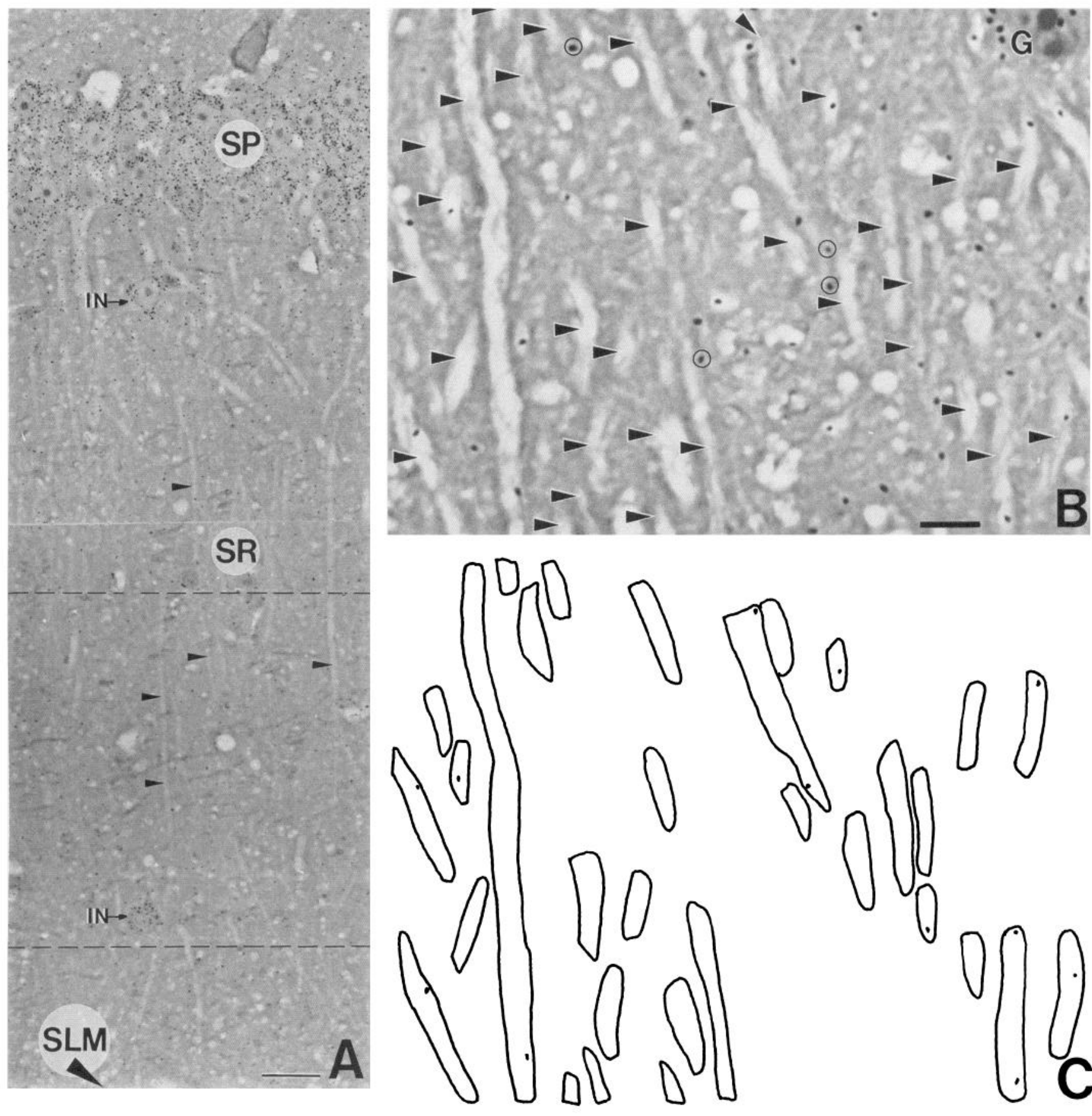

Figure 1. CA1 region of the guinea pig hippocampal slice: analysis of ${ }^{3} \mathrm{H}$-leucine incorporation into dendrites. $A$, Photomicrograph of CA1 from the stratum pyramidale $(S P)$ to the border of stratum lacunosum moleculaire $(S L M)$ showing pyramidal cells in stratum pyramidale and their apical dendrites within stratum radiatum $(S R)$. Two interneurons $(I N)$ are present in this field. Several long apical dendrites within this section are indicated by the arrowheads. The region between the broken lines indicates the location and size of the fields that were analyzed for ${ }^{3} \mathrm{H}$ incorporation into dendrites. Note that the density of grains (black dots) is similar over all neuronal cell bodies, including interneurons and those in the pyramidal layer. $B$, Higher-power photomicrograph from a typical region in CAl stratum radiatum that was used for analysis. It shows dendritic profiles and the overlying developed silver grains (black dots). Arrowheads indicate dendritic profiles that were traced for analysis. Circles denote silver grains that were not drawn. $G$, glial cell. $C$, Camera lucida drawing of the dendrites in $B$ that were selected for analysis (see Materials and Methods for selection criteria). Grains overlying these dendrites are also shown. Drawings such as these were used to calculate grains $/ \mu \mathrm{m}^{2}$ of the selected dendrites. Scale bars: $A, 25 \mu \mathrm{m} ; B, 4 \mu \mathrm{m}$.

from a quite uniformly distributed uptake system, or from diffusion of free leucine within the cells following uptake.

Much of this study is focused on protein synthesis in the dendrites. It is thus important to note that not only somatic morphology (Feig and Lipton, 1990) but also dendritic morphology is very well preserved when this preincubation protocol is followed. This is shown in Figure 3. The only notable difference between neuropil in glutaraldehyde-fixed slices and per- 

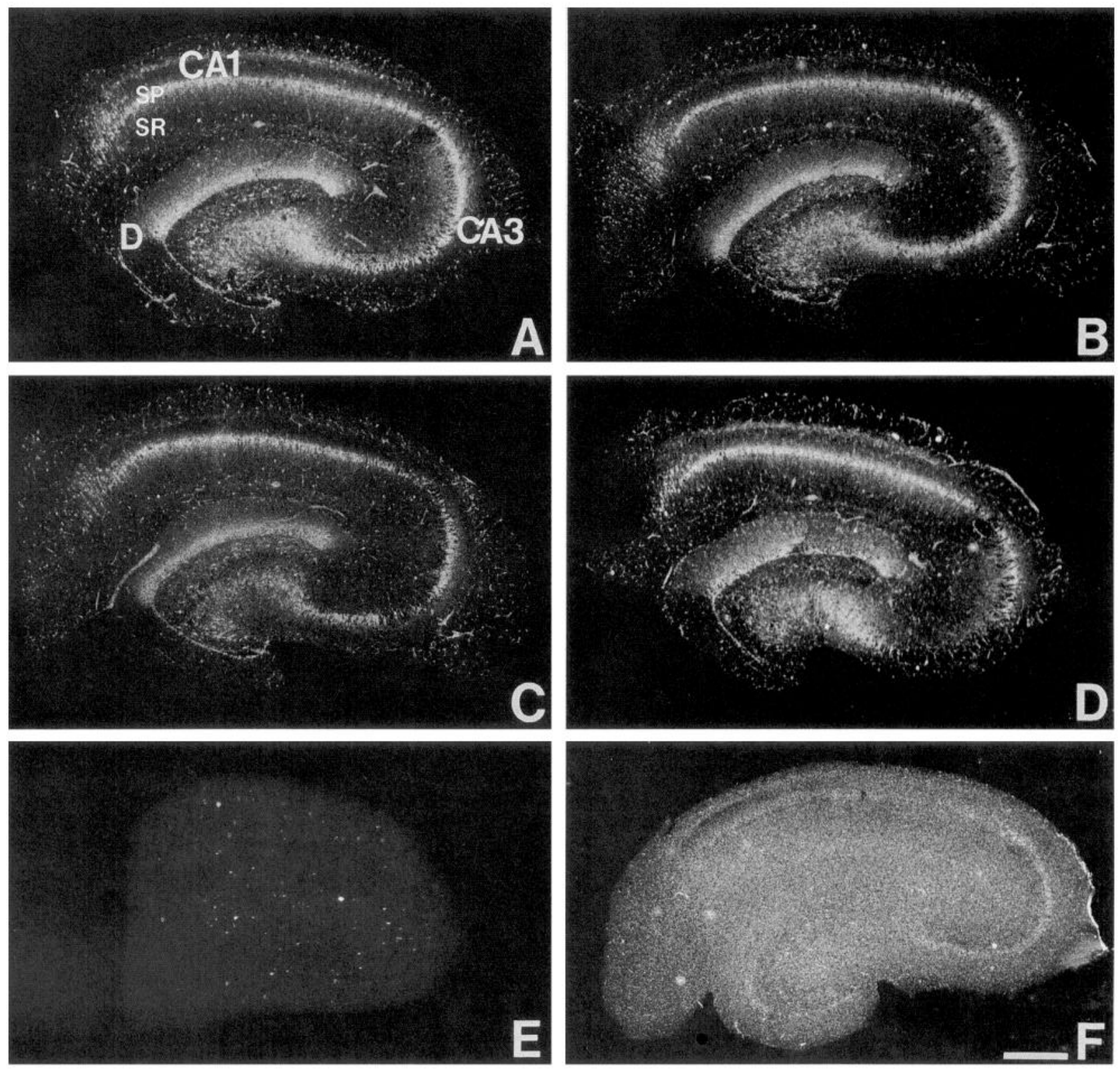

Figure 2. Protein synthesis in guinea pig hippocampal slice. $A-D$, Dark-field photomicrographs taken at different depths in a hippocampal slice $(A, 80 \mu \mathrm{m}$ from upper surface; $B, 200 \mu \mathrm{m} ; C, 320 \mu \mathrm{m} ; D, 440 \mu \mathrm{m})$. This slice was incubated for 30 min in ${ }^{3} \mathrm{H}$-leucine and immediately fixed in ice-cold 4\% paraformaldehyde. Frozen $40 \mu \mathrm{m}$ sections were taken through the slice and processed (see Materials and Methods) to reveal silver grains due to ${ }^{3} \mathrm{H}$-leucine incorporated into macromolecules. Note uniform labeling of major cell populations in CA1, CA3, and dentate gyrus (labeled $D$ in $A$ ) of each section. The punctate labeling in the stratum radiatum $(S R)$ denotes synthesis in the interneurons, glia, and capillary endothelial cells. The cells in the pyramidal cell layer $(S P)$ of CA1 are uniformly labeled throughout the slice. $E$, Dark-field photomicrograph of a $40 \mu \mathrm{m}$ frozen section $120 \mu \mathrm{m}$ from the surface of a slice that had been incubated with ${ }^{3} \mathrm{H}$-leucine in the presence of $(300 \mu \mathrm{M})$ cycloheximide, which inhibits protein synthesis. There is very little labeling over this slice (the scattered bright spots are artifacts), confirming that the label in $A-D$ represents newly synthesized protein. $F$, A dark-field photomicrograph of a $40 \mu \mathrm{m}$ section, $120 \mu \mathrm{m}$ from the surface of a slice incubated as in $E$ with cycloheximide but fixed in $2 \%$ glutaraldehyde, $2 \%$ paraformaldehyde to retain free ${ }^{3} \mathrm{H}$-leucine. In this case, diffuse label is present over all regions of the hippocampus. Scale bar, $670 \mu \mathrm{m}$.

fusion-fixed brain is the increased extracellular space (Fig. $3 A, B$ ). Organelles, spines, and synapses in the slice are not notably different from their counterparts in situ. In the studies of protein synthesis, tissue had to be fixed in paraformaldehyde so that free ${ }^{3} \mathrm{H}$-leucine would not be retained. In this case, the fixation led to loss of microtubules in the dendrites with a concomitant alteration in the morphology of the dendritic cytoplasm (Fig. $3 C$ ). This fixation of course occurred after the experimental procedures were complete.

\section{Protein synthesis in dendrites and somata of resting slices}

Incorporation of ${ }^{3} \mathrm{H}$-leucine into dendrites of unstimulated cells was approximately $10 \%$ the level of incorporation into the cell somata (Fig. 4, first and third bars). Cycloheximide reduced the label over cell somata by $90 \%$, indicating that almost all the incorporation is de novo synthesis of protein. In contrast, cycloheximide had no effect on label over dendrites (Fig. 4). Thus, in the resting state there is no measurable extramitochondrial 

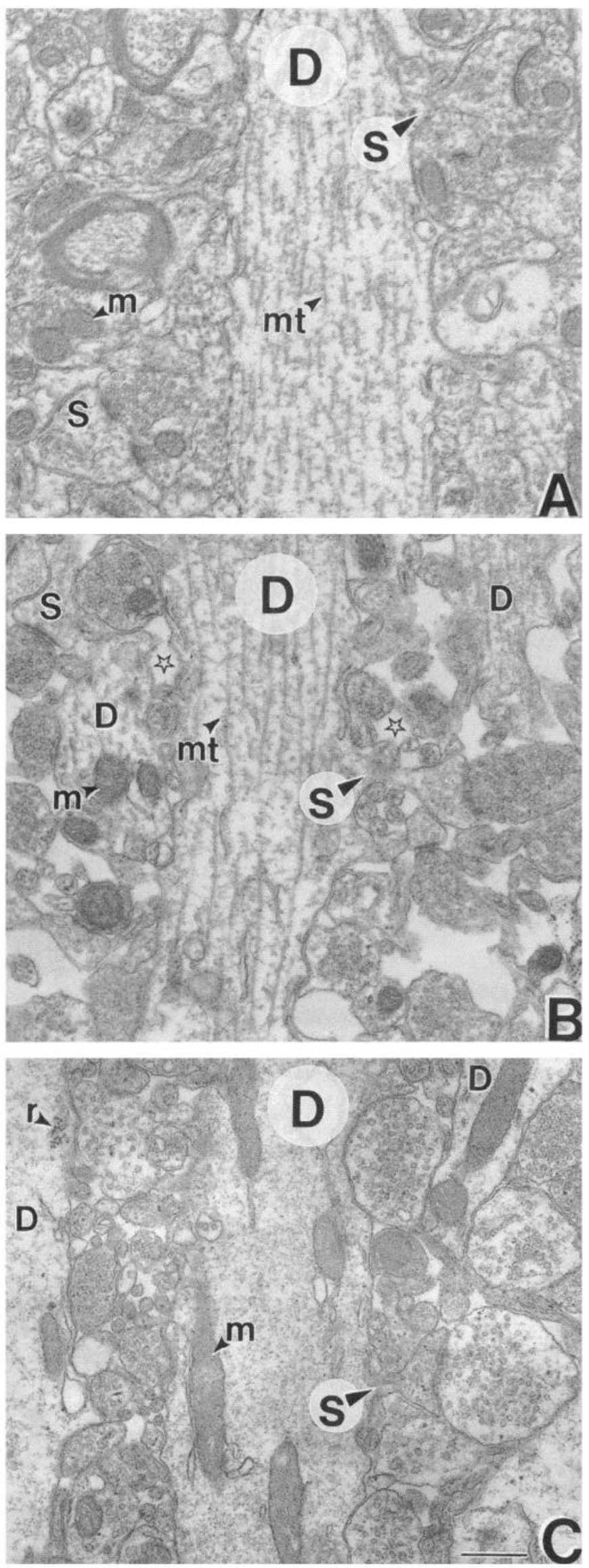

protein synthesis in the distal dendrites of the CAl pyramidal layer cells.

As shown in Figure 4, the cycloheximide-insensitive label is approximately the same in dendrites and cell somata. Its composition is unknown. The most likely components are mitochondrial protein synthesis, and formation of leucyl-tRNA. About half this label disappears when fixation is delayed by 4 min following the $3 \mathrm{~min}$ exposure period. The rest remains for at least $30 \mathrm{~min}$ (S. Feig and P. Lipton, unpublished observations)

\section{Effects of stimulation and of carbachol on ${ }^{3} \mathrm{H}$ incorporation into protein}

Stimulating the Schaffer collaterals with the standard stimulus paradigm slightly decreased label over paraformaldehyde-fixed dendrites. Exposure of slices to $50 \mu \mathrm{M}$ carbachol for $35 \mathrm{~min}$ had a similar effect. However, when the standard stimulus paradigm was applied in the presence of $50 \mu \mathrm{M}$ carbachol, the result was quite different. There was a nearly threefold increase in silver grains per unit area of dendrite (Fig. $5 A$ ). There was no accombanying effect of the associated stimuli on label over cell somata; in ract, there was a small decrease in label when the two conditions were combined (Fig. $5 A$ ). The micrographs (Fig. $5 B, C$ ) show portions of stratum radiatum from a pair of unstimulated and stimulated slices that were exposed to carbachol. The only notable difference is the increased number of grains over dendrites in the stimulated slice.

\section{Relationship of increased ${ }^{3} \mathrm{H}$ incorporation to increased protein synthesis}

Three further studies were done to determine whether the enhanced ${ }^{3} \mathrm{H}$ incorporation due to carbachol and Schaffer collateral stimulation was an activation of protein synthesis.

The increased incorporation may have resulted from increased free ${ }^{3} \mathrm{H}$-leucine uptake into the dendrites, and a resulting rise in the specific activity of the precursor amino acid pool. This was tested by including cycloheximide in the incubation medium prior to and during incubation with ${ }^{3} \mathrm{H}$ and then fixing the tissue in glutaraldehyde/paraformaldehyde rather than para-

Figure 3. Comparison of dendrite morphology in situ and in the slice. $A$, Electron micrograph of a hippocampal CA1 dendrite (labeled $D$ ) in stratum radiatum from a guinea pig perfused with fixative containing $2 \%$ glutaraldehyde, $2 \%$ paraformaldehyde. This is a presumed pyramidal cell dendrite as it has a dendritic spine $(S$ with arrowhead $)$. Note numerous microtubules $(m t)$. Mitochondria $(m)$ are indicated as well as a dendritic spine that is not attached to a dendrite in this section ( $S$ without arrowhead). B. Electron micrograph of hippocampal CAI dendrite (labeled with large $D$ ) from the stratum radiatum of a hippocampal slice immersion fixed in the same fixative used in $A$. This is also a presumed pyramidal cell dendrite because of the dendritic spine ( $S$ with arrowhead); note the well-preserved microtubules $(\mathrm{mt})$. Sample mitochondria $(m)$ are indicated for comparison with those in $A$. Note also other small dendritic (also labeled $D$ ) profiles and spine ( $S$ without arrowhead) present in the field. While the morphological preservation of the cellular elements is remarkably similar to that of perfusion-fixed tissue, a notable characteristic of these immersion-fixed slices is the appearance of extracellular space (stars). $C$, Electron micrograph of hippocampal CA1 dendrite $(D)$, from the stratum radiatum of a hippocampal slice, prepared and incubated exactly as the slice for $B$ but immersion fixed in solution containing $4 \%$ paraformaldehyde and no glutaraldehyde. This is also a presumed pyramidal cell dendrite because of the dendritic spine. Note the absence of microtubules; the dendrite is now filled with an amorphous flocculent material. However, mitochondria $(m)$ are well preserved. There is a cluster of ribosomes $(r)$ present in a neighboring dendrite (smaller $D$ ). Scale bar, $0.5 \mu \mathrm{m}$. 
$\left({ }^{3} \mathrm{H}\right)$ Incorporation

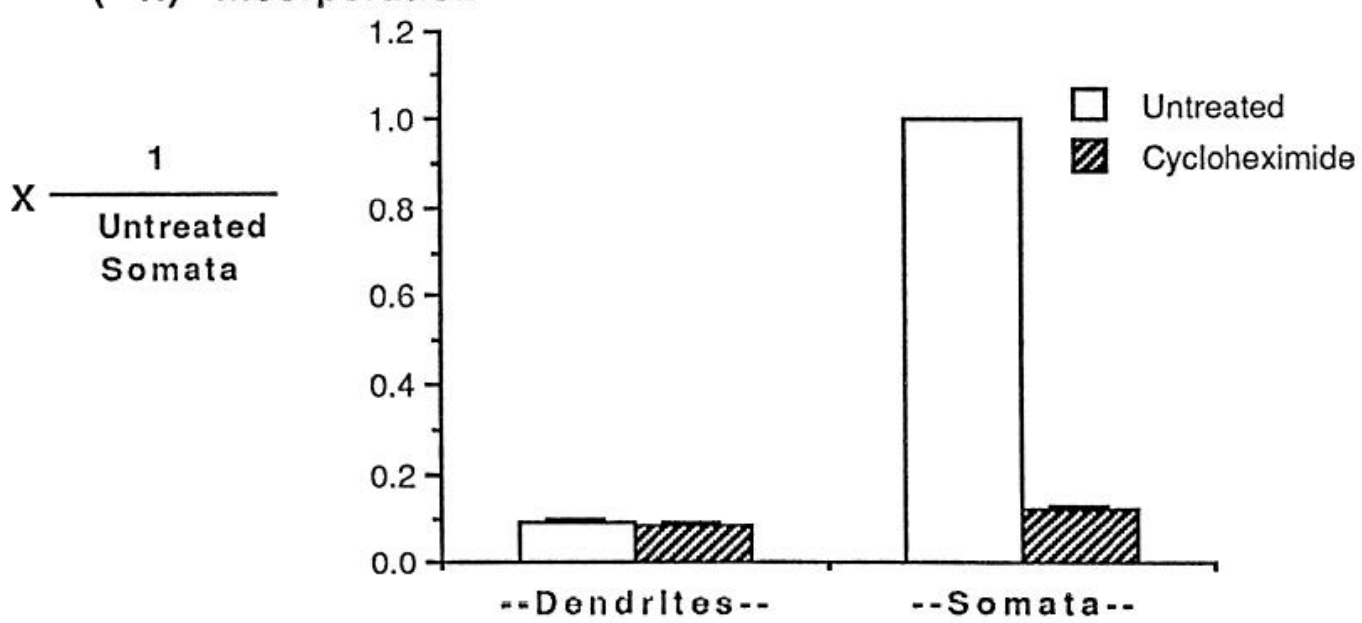

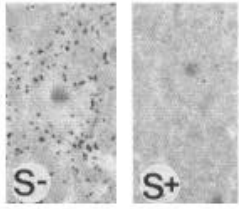

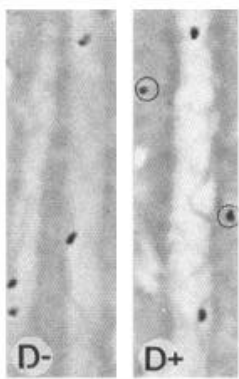

Figure 4. Cycloheximide blocks ${ }^{3} \mathrm{H}$ incorporation into cell somata but not into dendrites in unstimulated slices. Cycloheximide-treated slices were incubated with cycloheximide $(300 \mu \mathrm{M})$ for $15 \mathrm{~min}$ prior to and during exposure to ${ }^{3} \mathrm{H}$-leucine. Untreated slices were maintained in standard buffer. All slices were exposed to ${ }^{3} \mathrm{H}$-leucine for $3 \mathrm{~min}$ prior to fixation in paraformaldehyde. In histogram, bars are means of 11 pairs of slices from five experiments. Background grain density, measured in dendrites of slices unexposed to ${ }^{3} \mathrm{H}$, averaged $15 \%$ ( $\pm 4 \%$ ) of the value in resting dendrites. This was not subtracted in these histograms. Photomicrographs show cell somata $(S)$ and dendrites $(D)$ from both control $(-)$ and cycloheximidetreated $(+)$ groups. Dots are developed silver grains. Note the dramatic drop in label over somata in the cycloheximide treated slices, and the apparent lack of any difference over the dendrites.
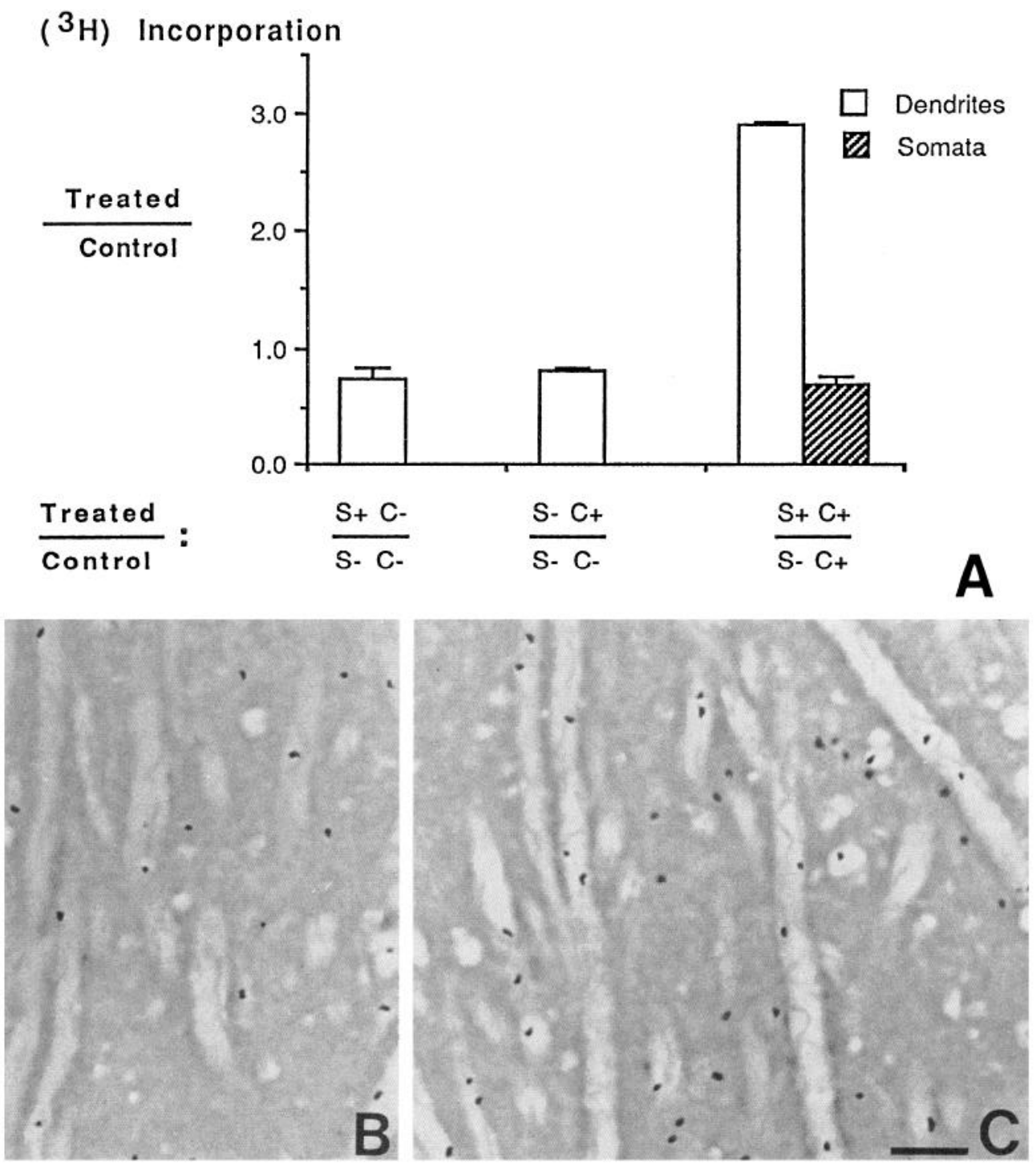

Figure 5. Effects of Schaffer collateral stimulation and carbachol on ${ }^{3} \mathrm{H}$-leucine incorporation into dendrites and somata. $A, S$ denotes standard stimulus paradigm; $C$ denotes carbachol. Members of a pair of slices were subjected to either the treated or control conditions shown, and then both slices were exposed to ${ }^{3} \mathrm{H}$-leucine for $3 \mathrm{~min}$. Ratios of ${ }^{3} \mathrm{H}$ incorporation in the two conditions were averaged and the results are shown in the four bars. Stimulus alone ( first bar) decreased incorporation into dendrites $(p<0.05)$; carbachol alone (second bar) decreased incorporation into dendrites $(p<0.005)$. Combining the two conditions (third bar) increased incorporation into dendrites threefold $(p<0.005)$ and decreased incorporation into cell somata $(p<0.01)$. $(n=$ seven pairs for each group). $B$ and $C$, Light micrographs of regions from stratum radiatum of the unstimulated $(B)$ and stimulated $(C)$ slices that were members of an experimental pair that was exposed to carbachol. Note the increased density of grains over dendrites in $C$ compared to $B$. Scale bar, $3 \mu \mathrm{m}$. 
Figure 6. The effects of stimulation and carbachol on $\left({ }^{3} \mathrm{H}\right)$ incorporation in the presence of cycloheximidc. All slices were exposed to carbachol $(50 \mu \mathrm{M})$ and cycloheximide $(300 \mu \mathrm{M})$. Cycloheximide was added 10 min prior to ${ }^{3} \mathrm{H}$ leucine. Fixatives were $2.5 \%$ glutaraldehyde, $2 \%$ paraformaldehyde, which measures the accumulation of precursor, and paraformaldehyde alone, which allows the washout of free ${ }^{3} \mathrm{H}$-leucine.

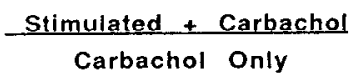

formaldehyde alone (see Materials and Methods). The combined stimuli did not increase label in these conditions (Fig. 6), showing that the stimuli do not enhance precursor uptake.

The observed increase may have been ${ }^{3} \mathrm{H}$ incorporation into a fraction other than newly synthesized protein. However, there was no increase in label over paraformaldehyde-fixed tissue when cycloheximide was included in the buffer (Fig. 6).

Synthesis is measured as grains per unit dendritic area, so the measured increase may have resulted from a narrowing of dendrites rather than an increase in protein synthesis. Thus, the mean width of dendrites in stimulated and nonstimulated slices was compared. Width was calculated by dividing the area of a dendrite by its longest dimension. Six pairs of slices were analyzed. Eight to ten dendritic profiles in each slice were measured. There was no difference between the mean width of dendrites in the two groups $(1.50 \pm 0.04 \mu \mathrm{m}$ in carbachol only vs $1.53 \pm 0.03 \mu \mathrm{m}$ in carbachol + stimulation).

Effects of a different stimulus pattern and of muscarinic and NMDA receptor antagonists on the increased protein synthesis

The effect was tested of altering the stimulus pattern to eliminate the high-frequency episodes while maintaining the same net number of stimuli. A steady stimulation at $1 \mathrm{~Hz}$ was applied throughout the 20 min period. In contrast to the effect of the intermittent higher-frequency trains, the steady lower-frequency activity did not enhance ${ }^{3} \mathrm{H}$-leucine incorporation into the tissue (Fig. 7C).

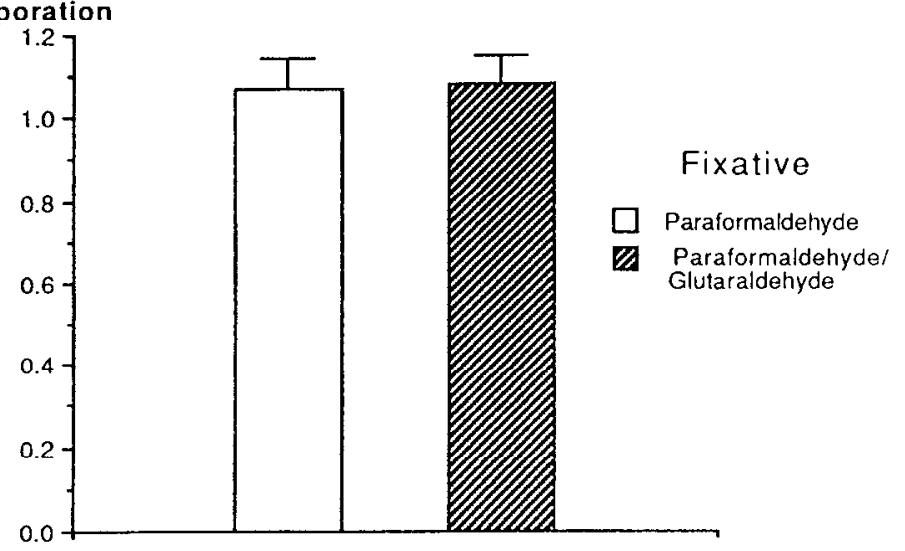

The receptor types involved in the activation of synthesis were examined by using the general muscarinic receptor antagonist atropine and the NMDA receptor antagonist D-aminophosphonovalerate (D-APV). Each of these inhibitors completely blocked the synthesis activated by combined carbachol and Schaffer collateral stimulation (Fig. $7 A, B$ ).

\section{Effects of different conditions on field potentials during patterned stimulation}

It is important to establish the extent to which any of the observed effects on protein synthesis might be explained by actions on electrophysiological responsiveness of the pyramidal neurons. If a treatment alters the magnitude of the population response, or the ability of the slice to maintain the response throughout the stimulation interval, protein synthesis might be affected.

Except for one instance, the different treatments had no effect on the four parameters of the response that were examined (Table 1). These four parameters are most easily understood by reference to Figure 8 , which is a diagrammatic representation of the standard stimulus paradigm.

(1) None of the treatments, including carbachol, carbachol + atropine, and carbachol + D-APV, significantly altered the magnitude of the population spike prior to the patterned stimulation, although $50 \mu \mathrm{M}$ carbachol did produce a transient depression in some cases (Fig. 9A). Cycloheximide (300 $\mu \mathrm{M})$ was added after the termination of the second stimulation period (Fig. 8), so its
Figure 7. Effects of transmitter antagonists and low-frequency stimulation on protein synthesis in dendrites. Pairs of slices were exposed to $50 \mu \mathrm{M}$ carbachol in the electrophysiological chamber and one of the slices was stimulated. For $A$ and $B$ either atropine (5 $\mu \mathrm{M} ; n=5)$ or D-APV $(50 \mu \mathrm{M} ; n=6)$ was added $15 \mathrm{~min}$ before beginning the standard stimulus paradigm. For $C$, no drug was added but a steady stimulus of $1 \mathrm{~Hz}$ was applied throughout the 20 min stimulation period $(n=4)$ instead of the standard stimulus paradigm. Three pairs of slices using the standard stimulus paradigm in the absence of any drugs were run as parts of these experiments and the ratio for these was 2.15 \pm 0.32 . For these treatments the only significant effect is a decrease in ratio for $B(p<0.05)$.

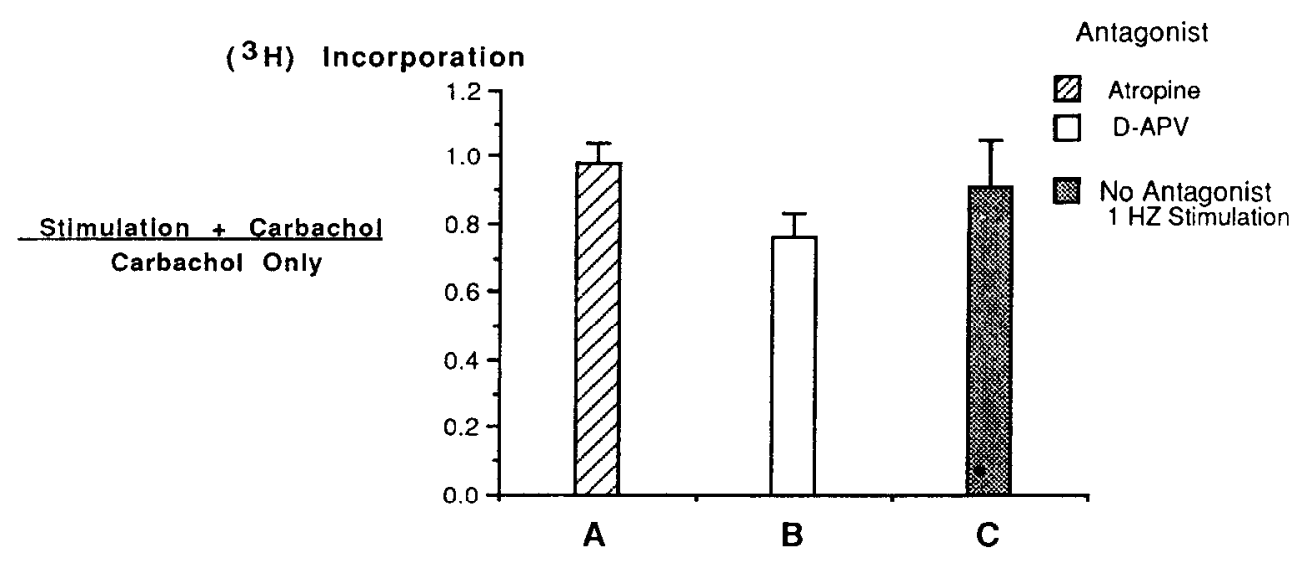




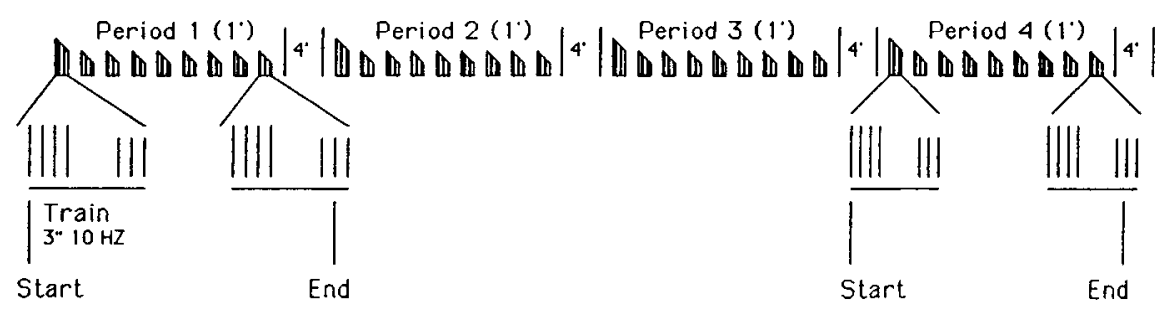

Figure 8. Diagrammatic representation of standard stimulus paradigm. Vertical lines represent population spike responses. Periods $1-4$ are 1 min long, during which stimulus trains of $3 \mathrm{sec}$ duration are separated by $4 \mathrm{sec}$ of silence. These are shown by the nine groups of population spikes in the top row and the expanded scale insets in the second row. These periods are separated from each other by 4 min, during which no stimulus is applied. The stimulus train is shown in some detail; the start period and end period data in Table 1 are averages of the first four and last four population spikes of the first and last stimulus trains in that period, respectively.

effect on the population spike could not be measured. However, cycloheximide, added at this time, did not affect the ratio of the spike height at the beginning of the fourth minute of stimulation to that at the beginning of the first (Table 1), indicating it did not affect the basal response.

(2) In none of the cases did the response decrement between the start of the first stimulus period and that of the fourth (Table 1).

(3) The events during each $1 \mathrm{~min}$ stimulus period are diagrammed in Figure 8. Except for D-APV (see below), there was only a slight decrement with time in the magnitude of the first spike of successive trains. Within a train, after an initial increase in height and addition of a second spike to the response, there was a small gradual decrement in spike height (Fig. 9B,C). The overall effects of these two changes are documented in the last two columns in Table 1 (see also Fig. 8). Table 1 shows that this parameter is similar for all the treatments except D-APV.

(4) The decrement during a stimulus period was very pronounced when D-APV was present (Table 1). This occurred because of an abrupt drop in the height of all the spikes in a train, not an increased decrement within the train. This took place between the second and fourth trains. The drop did not occur in all slices. In four out of six cases there was a large fall (Fig. 9D), while in two cases there was no fall (Fig. 9E). Thus, in some cases NMDA receptor activation appears necessary for maintenance of prolonged stimulation at moderate frequencies. This phenomenon was not explored further in the present study.

\section{Discussion}

Associating patterned Schaffer collateral stimulation with carbachol increased incorporation of ${ }^{3} \mathrm{H}$-leucine into macromolecules in dendrites of cells in the CAl region of the guinea pig hippocampal slice. It is very likely that this represents activation of de novo protein synthesis. (1) It is completely blocked by cycloheximide at concentrations that blocked synthesis in the resting pyramidal cell somata by $90 \%$ in this study and that are known to inhibit protein synthesis severely in many cell populations (Pestka, 1971), including hippocampal slices (Lipton and Heimbach, 1977). (2) It is very unlikely that the increased ${ }^{3} \mathrm{H}$ incorporation into newly synthesized protein is due to an increase in precursor specific activity. Although specific activity cannot be measured in the dendrites, several considerations argue against this possibility. Most importantly, uptake of ${ }^{3} \mathrm{H}-$ leucine was unaffected by the combined stimuli. Thus, increased

Table 1. Effects of different treatments on population spike responses

\begin{tabular}{|c|c|c|c|c|}
\hline \multirow[b]{2}{*}{ Treatment } & \multicolumn{4}{|c|}{ Population spike amplitude ratios } \\
\hline & $\begin{array}{l}\text { Treated }^{a /} \\
\text { control }\end{array}$ & $\begin{array}{l}\text { Start period } 4 / \\
\text { start period } 1\end{array}$ & $\begin{array}{l}\text { End period 1/ } \\
\text { start period } 1\end{array}$ & $\begin{array}{l}\text { End period } 4 / \\
\text { start pcriod } 4\end{array}$ \\
\hline None & - & $\begin{array}{l}1.44 \pm 0.25 \\
\text { (4) }\end{array}$ & $0.95 \pm 0.06$ & $0.66 \pm 0.20$ \\
\hline $\begin{array}{l}\text { Carbachol } \\
(50 \mu \mathrm{M})\end{array}$ & $\begin{array}{l}1.05 \pm 0.10 \\
(5)\end{array}$ & $1.15 \pm 0.14$ & $0.68 \pm 0.12$ & $0.71 \pm 0.09$ \\
\hline $\begin{array}{l}\text { D-APV } \\
(50 \mu \mathrm{M})\end{array}$ & $\begin{array}{l}0.92 \pm 0.04 \\
(6)\end{array}$ & $1.05 \pm 0.02$ & $0.35 \pm 0.13^{* *}$ & $0.34 \pm 0.15^{* *}$ \\
\hline $\begin{array}{l}\text { Atropine }^{b} \\
(5 \mu \mathrm{M})\end{array}$ & $\begin{array}{l}0.88 \pm 0.12 \\
(4)\end{array}$ & $1.00 \pm 0.11$ & $0.83 \pm 0.15$ & $0.67 \pm 0.10$ \\
\hline $\begin{array}{l}\text { Cycloheximide }^{b} \\
(100 \mu \mathrm{g} / \mathrm{ml})\end{array}$ & - & $\begin{array}{l}0.98 \pm 0.09^{c} \\
(4)\end{array}$ & - & $0.54 \pm 0.19$ \\
\hline
\end{tabular}

\footnotetext{
Steady population spike amplitudes were attained while stimulating once every 2 min. Drugs were then added (except
} for cycloheximide) and a new steady state attained after $15 \mathrm{~min}$ at the same stimulation rate. The standard stimulation paradigm (SSP) was then started. In the case of cycloheximide, the drug was added 10 min after the start of SSP. The first column refers to events before beginning SSP. The last three columns refer to events during SSP. "Start period" (1 or 4) refers to the average magnitude of the first three spikes of the first or fourth minute of stimulation. "End period" ( 1 of 4 ) refers to the average magnitude of the last three spikes of the first or fourth minute of stimulation. Results are means \pm SEM. Numbers in parentheses refer to number of slices for that treatment.

" "Treated" is 15 min after adding drug; "control" is immediately before adding drug.

${ }^{b}$ Added in presence of carbachol.

c Cycloheximide added immediately after period 1 .

** Different from carbachol, $p<0.05$ 

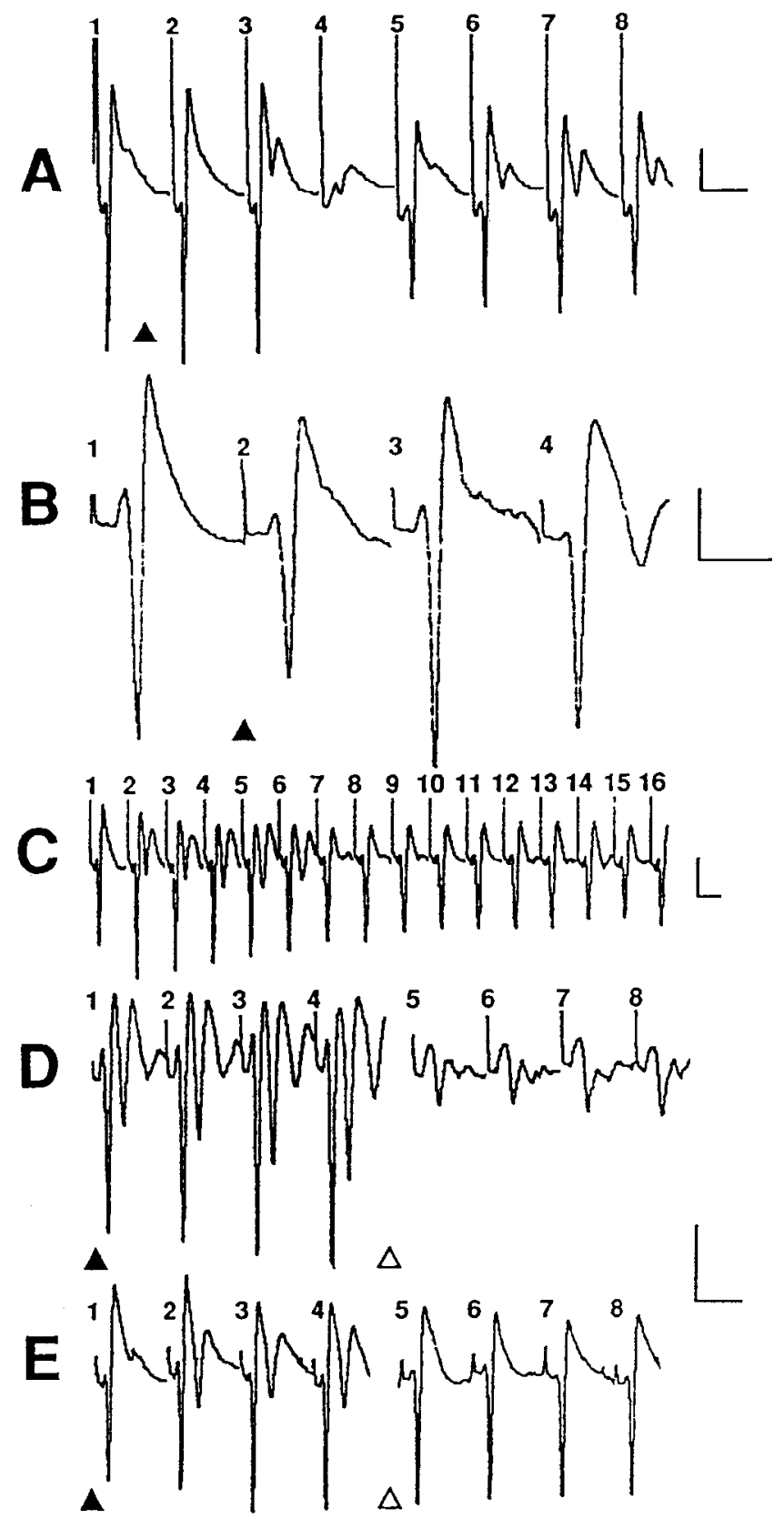

Figure 9. Effects of the various treatments upon field potentials. Field potentials were recorded in CAl pyramidal layer following stimulation of Schaffer collaterals in CA2. All field potential responses are numbered. In all cases the time scale refers to points during the field response. Intervals between field responses were different in the different traces. $A$, Effect of carbachol $(50 \mu \mathrm{M})$ on field potential prior to standard stimulus paradigm. Carbachol $(50 \mu \mathrm{M})$ was added after trace 1 (arrowhead), and the following traces were taken subsequently every $2 \mathrm{~min}$. There is often an appearance of a second spike, and almost always a transient decrease in the response, with a return to steady levels that vary with respect to the original level (see Table 1 ). $B$, The first three field potentials of a $10 \mathrm{~Hz}$ train that is part of the standard stimulus paradigm. The first trace is after $15 \mathrm{~min}$ in carbachol, immediately prior to delivery of the train pulse. Train begins at arrowhead; the population spike increased in amplitude (labeled 3 ) after the first trace and developed a second population spike (labeled 4) by the third trace. This pattern occurred in almost every case, including the cases when atropine and D-APV were added to the bath. $C$, First 15 field potentials from a train at $10 \mathrm{~Hz}$; standard stimulus paradigm began at second trace. Response 1 is after $15 \mathrm{~min}$ in carbachol. Response grows at first, and includes a second spike, and then falls off slightly to steady level (the level shown specific activity could only explain the increased incorporation if endogenous leucine in the dendrites were decreased to about one-third its control value by the stimuli. There is no apparent reason for this to occur. Furthermore, an increased specific activity of intracellular leucine should lead to increased incorporation into the cycloheximide-insensitive fraction, as it too presumably utilizes a pool of free cell leucine. No increase was seen, even though this basal incorporation represents a sizeable fraction of total incorporation. Finally, there is no incorporation into the cycloheximide-sensitive pool prior to stimulation, and a large incorporation into the pool afterward. Thus, an altered specific activity due to decreased endogenous leucine would have to initiate incorporation into a previously inaccessible pool. This seems extremely unlikely.

Absolute values of protein synthesis could not be measured. Average rates of synthesis in the dendrites did rise to approximately $20 \%$ of those in the cell somata as a result of the associated stimuli (combining data from Figs. 4, 5). This is sizable, especially considering the fact that there is no measurable synthesis in the resting state.

\section{Cell population affected}

The Schaffer collaterals form synapses with apical dendrites of pyramidal cells and dendrites of interneurons (Schwartzkroin and Kunkel, 1985; Ishizuka et al., 1990; Miles, 1990). The population of dendrites that was analyzed included those from pyramidal cells but may also have included those from interneurons throughout $\mathrm{CA} 1$, as these each send small numbers of vertically oriented dendrites into stratum radiatum. The latter appear to comprise about $20 \%$ of the dendritic field (Schlander and Frotscher, 1986; Sloviter, 1989). Since a large activation of synthesis in a small population of dendrites was not observed, it is very likely that activation of synthesis was not restricted to dendrites of interneurons. Therefore, while the activation of synthesis may have occurred in interneuron dendrites, it almost undoubtedly occurred in the apical dendrites of the pyramidal cells.

\section{Dendritic protein synthesis}

The relative contributions of dendritic flow and local synthesis to turnover of dendritic protein is poorly understood (Kreutzberg et al., 1973; Kiss, 1977; Grafstein and Forman, 1980). The density of polysomes in dendrites is far less than in cell somata (Peters et al., 1976; Steward et al., 1988), but the relative contributions of different components of flow and of local synthesis to supply of new protein have not been determined.

There is, however, good evidence that local synthesis of protein occurs in dendrites in certain instances. Polysomes are localized in dendrites of several neuronal types in situ, and their number is greatly increased during regeneration of synaptic connections following deafferentation (Steward, 1986), as is the amount of ribosomal RNA (Phillips et al., 1987), suggesting an active local protein synthesis. Furthermore, ${ }^{3} \mathrm{H}$-leucine is in-

in 16 is maintained throughout the train). $D$ and $E$, Effects of D-APV on stimulus trains. In both cases, stimulation was in presence of carbachol and D-APV. Traces $1-4$ are from first stimulus train during the first minute of stimulation (solid arrowhead). Traces 5-8 are from last stimulus train during that minute (open arrowhead). The marked decrease during the minute, shown in $D$, occurred in four out of six slices. In the other two slices, illustrated by $E$, there was no significant decrement during the minute. Calibration: $1 \mathrm{mV}, 10 \mathrm{msec}$. 
corporated into a cycloheximide-sensitive fraction of dendrites after they have been isolated from cultured hippocampal neurons (Torre and Steward, 1992), providing a very clear demonstration of nonmitochondrial synthesis of protein in dendrites.

In the present study, the incorporation time for ${ }^{3} \mathrm{H}$-leucine was limited to $3 \mathrm{~min}$ in order to minimize any opportunity for a contribution from dendritic flow in the intact tissue. The most rapid dendritic flow has been measured at a rate of about 50 $\mu \mathrm{m} / \mathrm{min}$ (Schubert et al., 1972; Kiss, 1977). At this rate it would take protein $4 \mathrm{~min}$ to flow to the dendritic region being examined once it had been synthesized and fully processed in the soma. The time required for synthesis in the soma and processing through the Golgi apparatus is not known for these cells but is approximately $4 \mathrm{~min}$ in other systems (Karrenbauer et al., 1990). Thus, a reasonable estimate for the minimal time required for somatically synthesized protein to reach the observed dendritic region is $5-10 \mathrm{~min}$. These considerations make it extremely unlikely that the new protein observed in dendrites after presentation of the associated stimuli could have arrived via flow. The time from initial exposure to ${ }^{3} \mathrm{H}$-leucine to fixation of the tissue was only $3 \mathrm{~min}$.

The short exposure time means that diffusion of ${ }^{3} \mathrm{H}$-leucine through the slice must be one of the rate-limiting factors for incorporation into the tissue. However, the possibility that the associated stimuli act by increasing the rate of diffusion through the slice (e.g., by increasing extracellular spaces) is eliminated by the lack of their effect on the 3 min uptake of ${ }^{3} \mathrm{H}$ precursor.

While there was significant synthesis of protein in the dendrites of carbachol-treated slices exposed to the standard stimulus paradigm, there was no measurable synthesis in the resting dendrites. This contrasts with cultured neurons described above, where dendritic synthesis occurs in the absence of exogenous stimulation (Torre and Steward, 1992). It is of interest that situations in which dendritic synthesis has been observed prior to the present study are ones in which dendrites were undergoing significant molecular reorganization. As described above, these include reestablishing synaptic connections in situ, or growth in cell culture (Steward et al., 1988). It may be that dendritic synthesis is coincident with remodeling of dendritic or synaptic structure and that the associated stimuli in the present study produce such conditions.

\section{Mechanisms of the activated synthesis}

The mechanisms by which dendrite synthesis is maintained at negligible basal levels in the resting slice, and by which the associated inputs activate it, were not determined. The activation is almost certainly at the level of translation rather than transcription because the flow of mRNA is several orders of magnitude too slow $(11 \mu \mathrm{m} / \mathrm{hr})$ to activate dendrite synthesis within 20 min of initiating the stimulus (Davis et al., 1990).

The most dramatic instance of rapid initiation of translation from a dormant state occurs during fertilization. Certain species of mRNA are activated, in many cases by apparent removal or modification of masking proteins (Richter, 1991). It is certainly possible that such mechanisms are involved here. Alternatively, several steps in mRNA translation are regulated by protein phosphorylation (Sarre, 1989; Morley et al., 1991) and both NMDA and muscarinic receptor activation affect protein kinases (El-Fakahany et al., 1988; Bading and Greenberg, 1991) and, via increases in $\mathrm{Ca}$, phosphatases.

A very important aspect of the present findings is the necessity for combining activation of the Schaffer collaterals with addition of carbachol in order to activate synthesis. The effects of the transmitter antagonists suggest that this represents a requirement for simultaneous activation of muscarinic and NMDA receptors. In four out of six cases, D-APV caused the magnitude of the response to decrease dramatically after the first two to four $10 \mathrm{~Hz}$ trains within each minute (Fig. 8). Thus, at least in some cases, NMDA receptor activation appears necessary to allow maintenance of prolonged responses to high-frequency activity. This cannot account completely for its role in the activation of protein synthesis, because in the two cases where DAPV did not lead to a reduced response it did prevent activation of synthesis (data from individual experiments, not shown). Thus, another effect of NMDA receptor activation is likely to be involved in the initiation of protein synthesis.

There are several intracellular interactions that might explain the strong synergism between the NMDA and muscarinic receptor mechanisms. Two of these are mediated by $\mathrm{Ca}$, activation of protein kinase $\mathrm{C}$ removes the depolarization block of NMDA receptor-mediated Ca channels (Chen and Huang, 1992), and muscarinic activation enhances protein kinase $\mathrm{C}$ activity in hippocampal slices (Bading and Greenberg, 1991). Also, muscarinic receptor activation greatly enhances the increase in intracellular free $\mathrm{Ca}$ caused by depolarization of cultured hippocampal pyramidal cells (Muller and Connor, 1991). Another potential interaction is not mediated by $\mathrm{Ca}$. There are now cases where both tyrosine and serine/threonine phosphorylations have been shown to be necessary for activation of enzymes; this is true for the important regulatory protein MAP kinase (Anderson et al., 1990). This is of particular interest as a model because NMDA receptor occupancy activates a tyrosine kinase (Bading and Greenberg, 1991) while the muscarinic receptor activates protein kinase C (El-Fakahany et al., 1988), a serine/threonine kinase. If such a multiple phosphorylation were necessary for activation of proteins involved in mRNA translation in the dendrites, it would explain the requirement for coactivation of the NMDA and muscarinic receptors.

\section{Significance of the effect}

There are several features that suggest that the activation of protein synthesis described here is important in long-term memory. Formation of long-term memory in many cases appears to be dependent upon ongoing protein synthesis at the time of learning (Flood et al., 1975; Eichenbaum et al., 1976; Grecksch and Matthies, 1980; Matthies, 1989), upon ongoing activity of the muscarinic cholinergic system (Dunnett et al., 1982; Chrobak et al., 1989; Ridley et al., 1991), and upon NMDA receptors (Morris et al., 1986). These features reflect the properties of the associative protein synthesis described here. Also important is the fact that synthesis is activated from a negligible level, suggesting that the associated stimuli produce a qualitative, as distinct from quantitative, change in dendritic protein. The fact that low-frequency stimulation did not lead to protein synthesis while patterned stimulation, of the type likely to pertain during exploratory activity in the animal, did, strengthens the connection between the increased synthesis and plasticity. Low levels of activity will not activate protein synthesis. Clearly, such arguments are not conclusive. However, they are consistent with a conclusion that the activation of protein synthesis seen here makes a contribution to synaptic plasticity during learning. The nature and function of the proteins whose synthesis is activated are not known. The two species of mRNA that have so far been 
identified in distal dendrites are those encoding the regulatory protein MAP- 2 and the $\alpha$-subunit of calmodulin dependent protein kinase II (Burgin et al., 1990; Kleiman et al., 1990).

\section{References}

Abdul-Ghani A-S, Boyar MM, Couthino-Netto J, Bradford HF (1980) Effect of stimulation on the incorporation of ${ }^{14} \mathrm{C}$ from glial and neuronal specific substrates into brain proteins in vivo and in vitro. $\mathrm{J}$ Neurochem 35:170-175.

Anderson NG, Maller JL, Tonks NK, Sturgill TW (1990) Requirement for integration of two distinct phosphorylation pathways for activation of MAP kinase. Nature 343:651-653.

Bading H, Greenberg ME (1991) Stimulation of protein tyrosine phosphorylation by NMDA receptor activation. Science 253:912-914.

Burgin KE, Waxham MN, Rickling S, Westgate SA, Mobley WC, Kelly PT (1990) In situ hybridization histochemistry of Ca/calmodulindependent protein kinase in developing rat brain. J Neurosci 10:17881798.

Chen L, Huang L-YM (1992) Protein kinase C reduces $\mathrm{Mg}^{2+}$ block of NMDA-receptor channels as a mechanism of modulation. Nature 356:521-523.

Chrobak JJ, Spates MJ, Stackman RW, Walsh TJ (1989) Hemicholinium-3 prevents the working memory impairments and the cholinergic hypofunction induced by ethylcholine aziridinium ion (AF64A) Brain Res 504:269-275.

Cowan WM, Gottleib DI, Hendrickson AE, Price JC, Woolsey TA (1972) The autoradiographic demonstration of axonal connections in the central nervous system. Brain Res 37:21-51.

Davis L, Burger B, Banker GA, Steward O (1990) Dendritic transport: quantitative analysis of the time course of somatodendritic transport of recently synthesized RNA. J Neurosci 10:3056-3068.

Dunlop DS, Van Elden W, Lajhta A (1974) Measurements of rates of protein synthesis in rat brain slices. J Neurochem 22:821-830.

Dunnett SB, Low WC, Iversen SD, Stenevi U, Bjorklund A (1982) Septal transplants restore maze learning in rats with fornix-fimbria lesions. Brain Res 369:151-162.

Eichenbaum H, Quenon B, Heacock A, Agranoff BW (1976) Differential behavioral and biochemical effects of regional injection of cycloheximide into mouse brain. Brain Res 101:171-176

El-Fakahany EE, Alger BE, Lai WS, Pitler TA, Worley PF, Baraban JM (1988) Neuronal muscarinic responses: role of protein kinase C. FASEB J 2:2575-2583.

Feig S, Lipton P (1990) NMDA receptor activation and $\mathrm{Ca}^{2+}$ account for poor pyramidal cell structure in hippocampal slices. J Neurochem 55:473-483.

Flood JF, Bennet EL, Orme AE (1975) Relation of memory formation to controlled amounts of brain protein synthesis. Physiol Behav 15: 97-102.

Gordon-Weeks PR (1988) RNA transport in dendrites. Trends Neurosci 11:342-343.

Grafstein B, Forman DS (1980) Intracellular transport in neurons. Physiol Rev 60:1167-1253.

Grecksch G, Matthies H (1980) Two sensitive periods for the amnesic effect of anisomycin. Pharmacol Biochem Behav 12:663-665.

Hendrickson AE, Moe L, Noble B (1972) Staining for autoradiography of the central nervous systcm. Stain Technol 47:283-290.

Hyson RL, Rubel EW (1989) Transneuronal regulation of protein synthesis in the brain-stem auditory system of the chick requires synaptic activation. J Neurosci 9:2835-2845.

Ishizuka N, Weber J, Amaral DG (1990) Organization of intrahippocampal projections originating from CA3 pyramidal cells in the rat. J Comp Neurol 295:580-623.

Karrenbauer A, Jeckel D, Just W, Birk R, Schmidt RR, Rothman JE, Wieland FT (1990) The rate of bulk flow from the golgi to the plasma membrane. Cell 63:259-267.

Kass IS, Lipton P (1982) Mechanisms involved in irreversible anoxic damage to the in vitro rat hippocampal slice. J Physiol (Lond) 332: $459-472$.

Kiss J (1977) Synthesis and transport of newly formed proteins in dendrites of rat hippocampal pyramid cells, an electron microscope autoradiographic study. Brain Res 124:237-250.

Kleiman R, Banker G, Steward O (1990) Differential subcellular localization of particular mRNA's in hippocampal neurons in culture. Neuron 5:821-830.
Kreutzberg GW, Schubert P, Toth L, Rieske E (1973) Intradendritic transport to postsynaptic sites. Brain Res 62:399-404.

Lipton P, Heimbach CJ (1977) The effect of extracellular potassium concentration on protein synthesis in guinea-pig hippocampal slices. J Neurochem 28:1347-1354.

Lipton P, Robacker K (1983) Glycolysis and brain function: (K) stimulation of protein synthesis and $\mathrm{K}$ uptake require glycolysis. Fed Proc 42:2875-2880.

Lisman J (1989) A mechanism for the Hebb and the anti-Hebb processes underlying learning and memory. Proc Natl Acad Sci USA 86: 9574-9578.

Matthies H (1989) In search of cellular mechanisms of memory. Prog Neurobiol 32:277-349.

Miles R (1990) Synaptic excitation of inhibitory cells by single CA3 hippocampal pyramidal cells of the guinea-pig in vitro. J Physiol (Lond) 428:61-77.

Morley SJ, Dever TE, Etchison D, Traugh JA (1991) Phosphorylation of eIF-4F by protein kinase C or multipotential S6 kinase stimulates protein synthesis at initiation. J Biol Chem 266:4669-4672.

Morris RGM, Anderson E, Lynch GS, Baudry M (1986) Selective impairment of learning and blockade of long-term potentiation by an $N$-methyl-D-aspartate receptor antagonist, AP5. Nature 319:774-776.

Muller RU, Kubie JL, Ranck JB Jr (1987) Spatial firing patterns of hippocampal complex-spike cells in a fixed environment. J Neurosci 7:1935-1950.

Muller W, Connor JA (1991) Cholinergic input uncouples $\mathrm{Ca}$ changes from $\mathrm{K}$ conductance activation and amplifies intradendritic $\mathrm{Ca}$ changes in hippocampal neurons. Neuron 6:901-905.

Nelson RB, Linden DJ, Hyman C, Pfenninger KH, Routtenberg A (1989) The two major phosphoproteins in growth cones are probably identical to two protein kinase C substrates correlated with persistence of long-term potentiation. J Neurosci 9:381-389.

Oliver MW, Baudry M, Lynch G (1989) The protease inhibitor leupeptin interferes with the development of LTP in hippocampal slices. Brain Res 505:233-238.

Pestka S (1971) Inhibitors of ribosome functions. Annu Rev Microbiol 25:487-562.

Peters A, Palay SL, de Webster F(1976) The fine structure of the nervous system: the neurons and supporting cells. Philadelphia: Saunders.

Peters T, Ashley CA (1967) An artifact in autoradiography due to the binding of free amino acids to tissue by fixatives. J Cell Biol 33:5360.

Phillips LL, Nostrand SJ, Chikaraishi DM, Steward O (1987) Increases in ribosomal RNA within the denervated neuropil of the dentate gyrus during reinnervation: evaluation by in situ hybridization using DNA probes complementary to ribosomal RNA. Mol Brain Res 2:251261.

Raley-Susman KM, Lipton P (1990) In vitro ischemia and protein synthesis in the rat hippocampal slice: the role of calcium and NMDA receptor activation. Brain Res 515:27-38.

Rao A, Steward O (1991) Evidence that protein constituents of postsynaptic membrane specializations are locally synthesized: analysis of proteins synthesized within synaptosomes. J Neurosci 11:28812895.

Richter JD (1991) Translational control during early development. Bioessays 13:179-183.

Ridley RM, Thornley HD, Baker HF, Fine A (1991) Cholinergic neural transplants into hippocampus restore learning ability in monkeys with fornix transections. Exp Brain Res 83:533-538.

Rogers AW (1973) Techniques of autoradiography. Amsterdam: Elsevier.

Sarre TF (1989) The phosphorylation of eukaryotic initiation factor 2: a principle of translational control in mammalian cells. Biosystems 22:311-325

Schlander M, Frotscher M (1986) Non-pyramidal neurons in the guinea pig hippocampus. A combined Golgi-electron microscope study. Anat Embryol (Berl) 174:35-47.

Schubert P, Kreutzberg GW, Lux HD (1972) Neuroplasmic transport in dendrites: effect of colchicine on morphology and physiology of motoneurones in the cat. Brain Res 47:331-343.

Schwartzkroin PA, Kunkel DD (1985) Morphology of identified interneurons in the CAl regions of guinea-pig hippocampus. J Comp Neurol 232:205-218.

Sloviter RS (1989) Calcium-binding protein (Calbindin-D28k) and 
parvalbumin immunocytochemistry: localization in the rat hippocampus with specific reference to the selective vulnerability of hippocampal neurons to seizure activity. J Comp Neurol 280:183-196.

Steward O (1986) Protein synthesis under dendritic spine synapses during lesion-induced synaptogenesis: evidence for regulation of reinnervation by the target cell. Exp Brain Res [Suppl] 13:173-188.

Steward O, Davis L, Dotti C, Phillips LL, Rao A, Banker G (1988) Protein synthesis and processing in cytoplasmic microdomains beneath postsynaptic sites on CNS neurons. Mol Neurobiol 2:227-261.

Thilmann R, Xie Y, Kleihus P, Kiessling M (1986) Persistent inhibition of protein synthesis precedes delayed neuronal death in postischemic gerbil hippocampus. Acta Neuropathol (Berl) 71:88-93.
Torre ER, Steward O (1992) Demonstration of local protein synthesis within dendrites using a new cell culture system that permits the isolation of living axons and dendrites. J Neurosci 12:762-772.

Uenishi N, Shors T, Finch CE, Nichols NR, Thompson RF (1991) Increased synthesis of two polypeptides in area CAl of the hippocampus in response to repetitive electrical stimulation. Brain Res 567: $248-252$.

White FP (1980) Protein synthesis in rat telencephalon slices: high amounts of newly synthesized protein found in association with brain capillaries. Neuroscience 5:173-178. 